\title{
FACTORS AFFECTING SERVICE QUALITY: A DESCRIPTIVE STUDY IN NORTH SURABAYA REGIONAL REVENUE MANAGEMENT UPT
}

\author{
Putri Nicha Asdewi \\ Magister Program of Human Resource Development, University of Airlangga, Indonesia \\ E-mail: nidewi.putri@gmail.com
}

\begin{abstract}
This study aims to find out, analyze and explain the factors that influence service quality in achieving good service quality at the North Surabaya Regional Revenue Management Unit. The type of research used is qualitative descriptive research. From the results of the study obtained an overall picture that the quality of service in the North Surabaya Regional Revenue Management UPT is good because of the interaction of Human Resources (HR) who are able to run a good service system and the right strategy in responding to people's desires and needs through service procedures standardized, innovative services and supporting facilities for infrastructure facilities. In addition, there is also a factor of leadership involvement in providing support for improving service quality and the existence of an organizational culture that can improve employee performance in providing the best service to the community.
\end{abstract}

\section{KEY WORDS}

Service quality, service system, service strategy, customers.

This research will describe the quality of public services by taking case studies at the Samsat Joint Office - North Surabaya Regional Revenue Management Unit. The existence of the Joint Office of Samsat was formed with the aim of serving the community in terms of motor vehicle tax payments (PKB), Motor Vehicle Transfer Fee (BBNKB) and Road Traffic Obligatory Donations (SWDKLLJ). As the main source of revenue for Regional Original Income (PAD), Motor Vehicle Tax (PKB) contributed significantly in increasing the APBD of East Java Province in order to improve the welfare of the people of East Java. Given the importance of the Motor Vehicle Tax (PKB) sector, government officials need to improve services to the maximum extent possible to obtain community satisfaction.

Statistical data on the Community Satisfaction Index (IKM) is data and information about the level of community satisfaction obtained from the results of quantitative and qualitative measurements of community opinion in obtaining services from public service providers by comparing expectations and needs (KepMenPan Number 25 of 2004). IKM Results in the North Surabaya Regional Revenue Management Unit in 2017 are in a good category and have increased every quarter.

Albrecht and Zemke in Dwiyanto (2006, p. 140-141) state that service quality is the result of interaction from various aspects, namely service strategies, service providers, service systems and customers (customers). Regarding motor vehicle tax services, services must collaborate and work together to be able to innovate which is one of the service strategies in attracting taxpayers. The use of technological innovations in the implementation of public services including samsat continues to be developed in order to create community satisfaction. In addition, if the consolidation of information technology goes well, it is expected that the level of public awareness or taxpayers in paying taxes also increases.

Along with the development of the era of globalization, people continue to demand the government to provide effective and efficient public services. People as increasingly selective service users to get quality services, they not only pay but demand good and quality service from the beginning to the end of the service. To be able to assess the quality of public services, an understanding is needed that can help understand how these public service institutions should work and produce quality output. The quality output here includes good output and in accordance with the level of community satisfaction. 
The purpose of this study is to find out, analyze and explain and explain the factors that influence service quality in achieving good service quality at the North Surabaya Regional Revenue Management Unit.

\section{LITERATURE REVIEW}

Concept of Public Services. Service is the provision of services (serving) the needs of people or communities that have an interest in the organization in accordance with the basic rules and procedures that have been set. Public services arise because of the existence of obligations as a process of organizing organizational activities.

Sinambela (2008:5) provides an understanding of public services: "Every activity carried out by the government on a number of people who have every activity that is profitable in a collection or unit, and offers satisfaction even though the results are not physically bound to a product".

According to the Decree of the Minister of Administrative Reform Number 63 of 2003, concerning General Guidelines for the Implementation of Public Services, public services are defined as: "All service activities carried out by public service providers as an effort to fulfill the need for receiving services and implementing statutory provisions".

The Concept of Service Quality. Some experts provide different definitions of quality. Kotler (2007: 64) explains the quality is: "Quality is the totality of features and characteristics of product service that is on the ability to satisfy stated or implied needs". Quality is the overall picture and characteristics of goods and services that show their ability to meet satisfaction and needs.

Quality is a word that for service providers is something that must be done well. Quality is seen as more comprehensive or holistic, where not only the results aspect is emphasized but also includes processes, environment and human resources (Hertanto, 2017).

Tjiptono and Chandra (2011: 180) say that service quality is a measure of how well the level of service provided is able to meet customer expectations. Whereas according to Ibrahim (2008: 22), the quality of public services is a dynamic condition that relates to products, services, people, processes, and the environment where the quality assessment is determined at the time of the provision of public services.

Based on the understanding of the quality of public services above, it shows that the focus of service quality is customers (the community receiving service). Because quality refers to everything that determines people's satisfaction, the service can be said to be of quality if it is in accordance with the perceptions, desires, and demands that can be utilized properly by the community.

Factors Affecting the Quality of Service. According to Albrecht and Zemke (1990) in Dwiyanto (2006: 140-141) states that: "The quality of public services is the result of interaction from various aspects, namely service systems, service providers, human resources. strategy and customers (customers) ". These three elements must be managed to achieve customer satisfaction. This interaction between strategy, system, and people (HR) determines management success and organizational service performance (Masdar, 2009: 47-48). According to Gaspersz (in Pasolong, 2013: 130) that the most important element of an organization is the customer (customer), for that it is necessary to identify exactly what the customer needs. This is in line with Tjosvold (in Pasolong, 2013: 130) saying that for organizations, "serving consumers is a moment of truth," the opportunity for organizations determines their credibility and capabilities.

Moenir (2002: 88) explains that there are several factors that support the running of a good service, namely the factor of staff awareness in the service, the ruling factor that becomes the basis of work, organizational factors, income factors, ability, and work skills factors and infrastructure. Walkins (in Tjiptono, 2002: 75-76) suggests 6 (six) factors in improving the quality of service on an ongoing basis. The six factors include leadership, education, planning, review, communication and appreciation, and recognition. 


\section{METHODS OF RESEARCH}

The research approach in this study is qualitative research with a type of descriptive research that is used to describe various symptoms and facts contained in social life in depth. In order to obtain an in-depth picture of a research phenomenon or problem, the researcher goes directly to the object of research by listening directly from the speaker, speaking in the truth about the conditions of service in accordance with the perspectives of each speaker as well as their position and role in their respective social systems. In terms of service providers, the number of informants is employees of the North Surabaya Regional Revenue Management who have a direct assignment to services and in terms of users who are served are community/taxpayers. Other sources are also used as archives as a source of data in the form of documents, photographs, statistical data and other important texts that are directly or indirectly related to research problems.

\section{RESULTS AND DISCUSSION}

Public services synonymous with service to the community is an activity aimed at meeting the needs of many people. The public service referred to in this study is how employees carry out their obligations in serving the public who will renew the STNK (pay for Motor Vehicle Taxes). Public services can work well if they know the factors that can affect service quality. Based on the results of interviews conducted by the author, the quality of service in the North Surabaya Regional Revenue Management UPT is good because of several influencing factors. Service quality based on the triangular service model consists of:

Service Strategy. To realize the commitment of service providers, it is necessary to have a good service strategy, so that efforts to repair and implement services can be carried out appropriately, quickly and according to community needs. Facilities in service should create innovative breakthroughs, for example, as said by Mr. Agus Huzaini as Samsat System Operator stating that:

"In improving services, many service innovations are needed, since East Java Governor Soekarwo still serves as Head of East Java Revenue Service, namely a pickup system. ball, for example, the community/taxpayer has a motorized vehicle and is confused or does not have the time to pay taxes, then as a public servant is in charge of helping to pay taxes with agreed time and then deliver back to the taxpayer so that taxpayers can enjoy that super special service, saving time, fast and satisfaction of preferred taxpayers" (Interview with Mr. Agus Huzaini, System Operator, September 6, 2018).

The attention of institutions to service quality includes various aspects, namely seen how to create awareness in Human Resources Apparatus (public servants) on the importance of improving service quality. There needs to be an application in the process of organizing the organization and the importance of service standards as guidelines for service performance.

Human Resources. Optimizing the quality of public services requires Human Resources as executors in terms of determining the quality of public services. As the executor of activities and processes for administering the government, the ability of these government apparatus also plays an important role in determining the level of quality of public services. There is a need for training for officials who are expected to improve the quality of the technical capabilities of the service personnel, so as to provide satisfaction for the community who use the service.

The Government Education and Training Program, better known as Diklat, was able to develop the habit of acting and behaving in carrying out tasks. Diklat will provide information on public services related to procedures and codes of service. As stated by Mr. Agus Huzaini as the system operator that: "I have participated in service ethics training because we are directly related to service so this training is important to me." (Interview with Mr. Agus Huzaini, System Operator, September 6, 2018).

Other informants said that the quality of service can be reflected in the performance of employees and the attitudes of officers as seen from the officers' ability to provide services in 
accordance with justice, friendliness and caring of officers. "Starting from the cohesiveness between employees and between agencies in this matter the Police and Jasa Raharja so as not to cause boredom with just that service, a form of joint gymnastics (flashmob) is carried out with the aim that employees feel refreshed in serving mandatory questions tax and provide the best service by giving a smile, greetings, and greetings. (Interview with Mr. Andreas Adi Widodo, SE, Tax Services Data Manager, 6 September 2018).

In addition, there is a need for a clear division of tasks with the role of the functions of each main task and function so as not to occur overlapping in jobs, especially public services. As stated by Mr. Agus Huzaini as the system operator that: "When there is a service disruption such as interference with the network, computer or server, my job as a system operator will coordinate with the central server section in the agency's office." (Interview with Mr. Agus Huzaini, System Operator, September 6, 2018).

In terms of service recipients, they were satisfied with the service at Samsat, as stated by Mr. Budi: "I have just validated a 5-year vehicle registration, the service is good even though it requires time due to a tax bleaching program but I am happy with the performance of employees who quickly and kindly serve all taxpayers. "(Interview with Mr. Budi, Taxpayer, 28 September 2018).

Service System. Providing the best service to the community requires an organized system. In addition to impacting on the speed of service, a good public service system can suppress extortion and corruption. Clear service requirements, time limits, procedures, and transparent service rates can encourage the level of public trust in services. Requirements for annual STNK renewal by carrying an identity (KTP / SIM / KK) and original vehicle registration with a service duration of 15 minutes. The informant said he was satisfied with the service in Samsat. "Efficient, Very Effective and Fast, no need to queue and be very satisfied with the service. Every time the extension will make its own payment to Samsat. "(Interview with Mr. Kwek Gien Sioe, Taxpayer, 10 October 2018).

From the opinion of the Head of the UPT and the Tax Services Data Manager, it was seen that to improve the quality of services more focused on the service system. What is focused on is arranging service mechanisms and service procedures, costs and time of service so that the community can be easier, faster and more transparent in receiving services. To implement it in writing by installing service procedures, mottos, slogans expected by employees to read and remember in the implementation of service performance. Whereas verbally direct or through formal meetings are conducted.

Other Factors Supporting Service. Quality relates to the attitudes and behavior of individuals in providing services to the public. Development of a new culture for employees in accordance with the organization's vision and mission as a service provider agent. Culture and service ethics continue to be developed by employees by placing themselves as servants of the community in accordance with the existing motto of Taxpayer Satisfaction and Excellent Service is Our Main Goal. Work culture is the basis for changing the way old work becomes a new way of working that is oriented to community satisfaction.

Leadership is also influential in determining the quality of public services. This can be seen from the role of the leader who participates directly in the field to control the quality of service. So that deficiencies can be directly followed up and motivated employees to provide the best service in every form of service.

\section{CONCLUSION}

Based on the results of interviews and discussions as stated earlier, it can be concluded that the service quality in the North Surabaya Regional Revenue Management Office UPT is good because:

Service strategy through service providers' commitment to improving service quality seen from the ongoing innovation and make it easier for people to pay motor vehicle taxes. The strategy of creating quality service through adequate supporting facilities and infrastructure is in the form of procedure instructions and service delivery lines and information service boards so that people get fast and appropriate services. 
Apparatus HR determines service quality seen from the ability of officers to provide services. Diklat is needed to develop the ability to act and behave. HR must also be able to understand the main tasks and functions so that they are focused on carrying out their work. In addition, the ability of human resources in coordination is needed to establish good relations between employees and other agencies in this case the Police and Services Raharja in providing services to the community.

The service system determines the quality of services seen from the clarity of service procedures related to cost, time and transparency of services both in written and oral forms.

Work Culture is reflected in attitudes and behaviors that become employee habits. In order for the service quality to be good, there are 10 names of shame culture so that employees do not do so. Through good leadership in directing employees and controlling employee performance will impact service quality to be good.

\section{SUGGESTIONS}

To maintain the quality of service that is already good, to continue to make breakthroughs through public service innovations in accordance with the needs of the community. Continue to improve service performance, especially for employees who come in direct contact with the service process in order to master the procedures and working mechanisms that have been set. Carry out socialization and knowledge transfers between employees so that the development of knowledge related to services can be spread evenly.

\section{REFERENCES}

1. Dwiyanto, Agus. (2006). "Mewujudkan Good Governance Melalui Pelayanan Publik. Yogyakarta: UGM Press.

2. Ibrahim, A. 2008. "Teori dan Konsep Pelayanan Publik Serta Implementasinya". Bandung: Mandar Maju.

3. Kotler, Philip dan Keller. (2007). "Manajemen Pemasaran Jilid I Edisi 12". Jakarta: PT. Indeks.

4. Masdar, S, dkk. (2009). "Manajemen Sumber Daya Manusia Berbasis Kompetensi untuk Pelayanan Publik". Surabaya: Pusat Penerbitan dan Percetakan Unair.

5. Sinambela, Lijan Poltak. (2008). "Reformasi Pelayanan Publik, Teori, Kebijakan dan Implementasi. Jakarta: PT Bumi Aksara.

6. Tjiptono, Fandy \& Chandra, Gregorius. (2011). "Service, Quality and Satisfaction Edisi 3". Yogyakarta: Andi Offset. 